\title{
Evidence for a heterotrophic subtropical northeast Atlantic
}

\begin{abstract}
The mean ( $\pm S E$ ) depth-integrated gross production $(P)$ of $2,600 \pm 271 \mathrm{mg} \mathrm{O} \mathrm{m}^{-2} \mathrm{~d}^{-1}$ derived from a compilation of data from nine cruises conducted between 19912000 in the subtropical NE Atlantic was found to be significantly lower ( $t$-test, $P=0.005 . N=33$ ) than the mean ( $\pm S E$ ) community respiration (R) of $3.821=276 \mathrm{mg} \mathrm{O}_{2} \mathrm{~m}^{-2}$ $\mathrm{d}^{-1}$. Two-thirds of the stations investigated were heterourophic, and the $P / R$ ratio of the communities tended to increase as $P$ increased, such that communities where $P<3.000 \mathrm{mg} \mathrm{O}_{2} \mathrm{~m}^{-3}$ $d^{-1}$ tended to be heterotrophic. The tendency for $R$ to exceed $P(P / R<1.0)$ was statistically significant (Wilcoxon ranked sign test, $P<0.05$ ) in the upper and deep layers of the photic zone, with an overall balance between $P$ and $R$ at intermediate depths. These results provide evidence that the subtropical NE Atlantic is a heterotrophic ecosystem, where planktonic communities respire more organic carbon than they produce. thereby acting as net sources of $\mathrm{CO}_{2}$.
\end{abstract}

The present debate on the role of planktonic communities in the oligotrophic ocean as carbon sources (i.e., heterotrophic. del Giorgio et al. 1997; Duarte and Agusti 1998; Duarte et al. 1999) or sinks (i.e., autotrophic. Williams 1998; Williams and Bower 1999) is flawed by the limited observational set available for any one oligotrophic oceanic province (Duarte et al. 1999; Williams and Bower 1999). Hence, heterotrophy could be a transient phenomenon rather than the dominant state of oligotrophic oceanic ecosystems (del Giorgio et al. 1997: Williams 1998). We have compiled estimates derived from studies in nine cruises conducted between 1991 and 2000 (Table 1) of planktonic gross production ( $P$ ) and community respiration ( $R$ ) that provide compelling evidence for heterotrophy $(R>P)$ in the photic layer of the subtropical NE Atlantic.

Net community production (NCP), community respiration $(R)$, and gross production (P) were determined by oxygen evolution (Strickland 1960) at two to seven depths. depending on cruises, from surface to below the $1 \%$ surface irradiance ( $40 \mathrm{~m}$ in upwelling waters. 75 to $100 \mathrm{~m}$ in open ocean waters). At each station, seawater samples were collected with a conductivity-temperature-depth (CTD) rosette system equipped with 24-L Niskin bottles. Samples were carefully siphoned using a silicone tube from Niskin bottles into four to eight replicate time-zero, dark, and light $125-\mathrm{ml}$ BOD bottles. Light bottles were incubated in situ or in temperature-controlled incubators simulating the in situ irradiance from dawn to dusk. Dark bottles were kept in temperaturecontrolled water baths $\left( \pm 0.1^{\circ} \mathrm{C}\right)$ at in situ temperature for 24 h. Dissolved oxygen was measured by the Winkler technique. following the recommendations of Carrit and Carpenter (1966), Bryan et al. (1976), and Grasshoff et al. (1983). The entire contents of the bottle were titrated in about $3 \mathrm{~min}$. The titration was controlled by an automated system, with colorimetric endpoint detection (Williams and Jenkinson 1982) or redox endpoint detection (Oudot et al. 1988). The average precision achieved in replicates samples rangen from 0.05 to 0.12 among cruises. $R$ was estimated from the difference in oxygen concentration between the time-zerd and dark bottles. Net community production on a daily basit was estimated as the difference between the light and time. zero bottles, corrected for respiration during the night. Gross production was calculated as the sum of net community production and respiration. We tested the effect of the long 24 . $h$ incubations conducted over the estimates of $P$ and $R$ bs testing for differences between $P$ estimates derived from 12 . versus 24 -h estimates and by examining $R$ at intervals of 4 , 8,12 , and $24 \mathrm{~h}$. Results from these experiments provided no evidence of altered rates in the 24-hr incubations used here. which was consistent with previous results for $P$ in the area (Marañón et al. 2000). The data set contained estimates of depth-integrated community metabolism for 33 stations ( $\geq 4$ depths) and an additional 147 estimates of volumetric community metabolism in surface and deep chlorophyll $a$ maximum waters (Table 1).

The estimates of gross production yield a significantly lower ( $t$-test, $P=0.005, N=33$ ) mean ( $I S E$ ) areal $\mathrm{P}$ of $2.600 \pm 271 \mathrm{mg} \mathrm{O}, \mathrm{m}^{-2} \mathrm{~d}^{-1}$ compared to the mean ( $\pm \mathrm{SE}$ ) $R$ of $3,821 \pm 276 \mathrm{mg} \mathrm{O} \mathrm{m}^{-2} \mathrm{~d}^{-1}$ within the photic layer of the subtropical NE Atlantic $(P / R$ ratio $=0.68)$. which also holds for the data collected in each of the individual years comprised in the data set. Two-thirds of the stations investigated were heterotrophic (Fig. 1), with a tendency for the $\mathrm{P} / \mathrm{R}$ ratio of the communities to increase as $\mathrm{P}$ increased. as described by the fitted regression equation

$$
\begin{array}{r}
\log P / R=-3.9 \div 1.12( \pm 0.12) \log P\left(m g O_{2} m: d^{\prime}\right) \\
\left(R^{2}=0.72, P<0.00001, N=33\right) .
\end{array}
$$

Communities where $P<3,000 \mathrm{mg} \mathrm{O}_{2} \mathrm{~m}: \mathrm{d}^{\cdot !}$ tended to be heterotrophic (i.e., $\mathrm{P} / \mathrm{R}<1$, Fig. 2). The analysis of a larger $(N=147)$ data set on volumetric community metabolism confirmed the general tendency for $R$ to exceed $P(89 \%$ of the estimates) at different depths in the water column (Fig. 3 ). The tendency for $R$ to exceed $P(P / R<1.0)$ was statistically significant (Wilcoxon ranked sign test, $P<0.005$ ) in the upper and deep layers of the photic zone, with an overall balance between $P$ and $R$ at intermediate depths (Fig. 3).

The results presented portray the subtropical NE Atlantic as a heterotrophic ecosystem, where planktonic communities respire more organic carbon than they produce, thereby acting as net sources of $\mathrm{CO}_{3}$. This conclusion is consistent with previous indications, derived from limited data sets. of an excess organic carbon demand relative to consumption in this area (Hernández-León et al. 1999; Agustí et al. in press). The values reported here do not represent. however, a time series, so the metabolic balance at the annual time scale re. mains unresolved. The seasonality of primary production in the area is, however, relatively well known and is characterized by a winter (late January-February) bloom (De León 


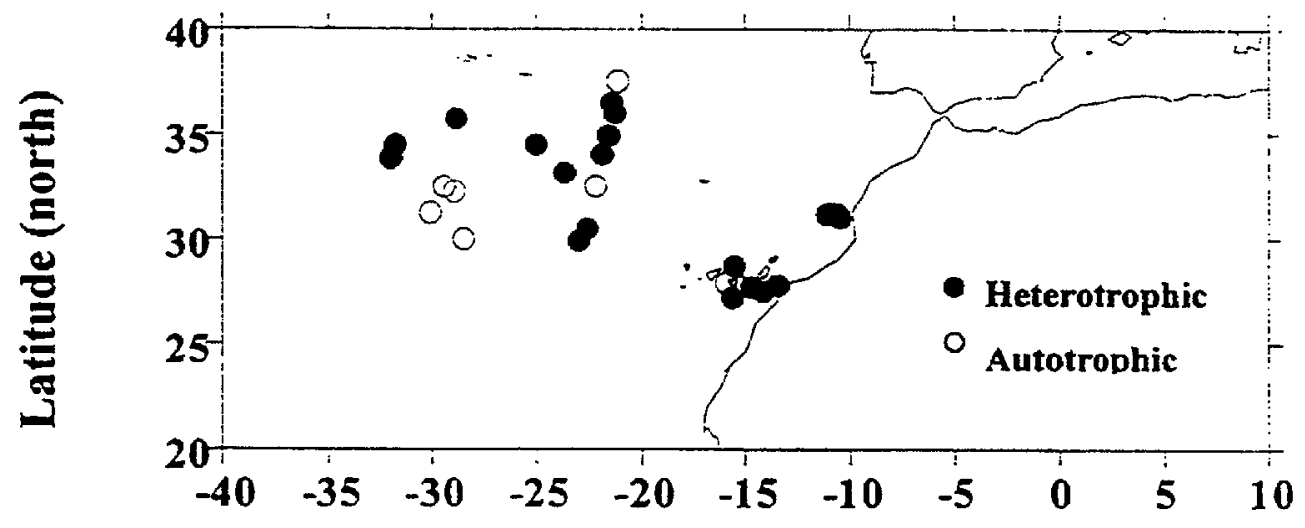

Longitude (east)

Fig. 1. The distribution of heterotrophic and autotrophic depth-integrated planktonic metabolism in stations studied in 1991, 1992, 1995, 1998, 1999, and 2000 in the subtropical NE Atlantic.

and Braun 1973; Davenport et al. 1999; Pacheco and Hernández-Guerra 1999; Aristegui et al. in press). The cruises conducted did not include this time of the year, so that it is possible that the annual metabolic balance of the region is more balanced than indicated by our results (cf. Sherr and Sherr 1996). A time series of community metabolism on the Canary coast has, however, indicated that the phytoplankton bloom, although associated with a period of net autotrophic metabolism, does not suffice to compensate the organic carbon deficit during the rest of the year (Aristegui et al. in press), so that the metabolic balance of the planktonic community remains heterotrophic at the annual time scale. This conclusion is further supported by the consideration that the climatological area-weighted mean $P$ for the subtropical NE Atlantic $\left(\approx 600 \mathrm{mg} \mathrm{C} \mathrm{m} \mathrm{m}^{-2} \mathrm{~d}^{-1}\right.$ for a composite of the Northeast Atiantic Subtropical Gyre and the Canary Coastal Current provinces in Longhurst et al. [1995]), somewhat lower than the mean $\mathrm{P}$, calculated assuming a photosynthetic quotient (PQ) of 1 , in our data set (975 $\left.\mathrm{mg} \mathrm{C} \mathrm{m}^{-2} \mathrm{~d}^{-1}\right)$, is well below the threshold of $P\left(\leq 1,125 \mathrm{mg} \mathrm{C} \mathrm{m}^{-2} \mathrm{~d}^{-3}\right)$ where the communities sampled were found to be heterotrophic. Yet, the problem of integrating from the daily time scales con-

Table 1. Summary of cruises and the stations occupied in the NE subtropical Attantic.

\begin{tabular}{lcc}
\hline \hline \multicolumn{1}{c}{ Date } & $\begin{array}{c}\text { Stations } \\
\text { occupied } \\
\text { (No.) }\end{array}$ & $\begin{array}{c}\text { Depths } \\
\text { sampled } \\
\text { (No.) }\end{array}$ \\
\hline Mar 1991 & 2 & 4 \\
Sep-Oct 1992 & 7 & 6 \\
Mar 1995 & 35 & 2 \\
Nov 1995 & 6 & 2 \\
Aug 1998 & 7 & 4 \\
Apr 1999 & 12 & 4 \\
Aug 1999 & 4 & 6 \\
Oct 1999 & 2 & 1 \\
Mar 2000 & 4 & $1-4$ \\
\hline
\end{tabular}

forming the empirical base for this study to longer tims: scales should be best addressed by the use of alternativ' approaches, such as oxygen and carbon mass balances which would-if in agreement with our results-strengtien the conclusions reached here. The use of alternative ap. proaches to the use of in vitro oxygen fluxes to test thi findings reported here is necessary because of possible changes in the rates during the incubations, although not detected here, which may lead to an overestimation of 1 . (e.g., Bender et al. 1999).

Our analysis, similar to previous studies (del Giorgio e al. 1997; Duarte and Agustí 1998; Williams 1998; Duarte el al. 1999; Williams and Bower 1999), does not inciude respiration by metazoans and plankton in the ocean's interior suggesting that the extent of heterotrophy in the subtropica' NE Atlantic should be even greater than indicated here

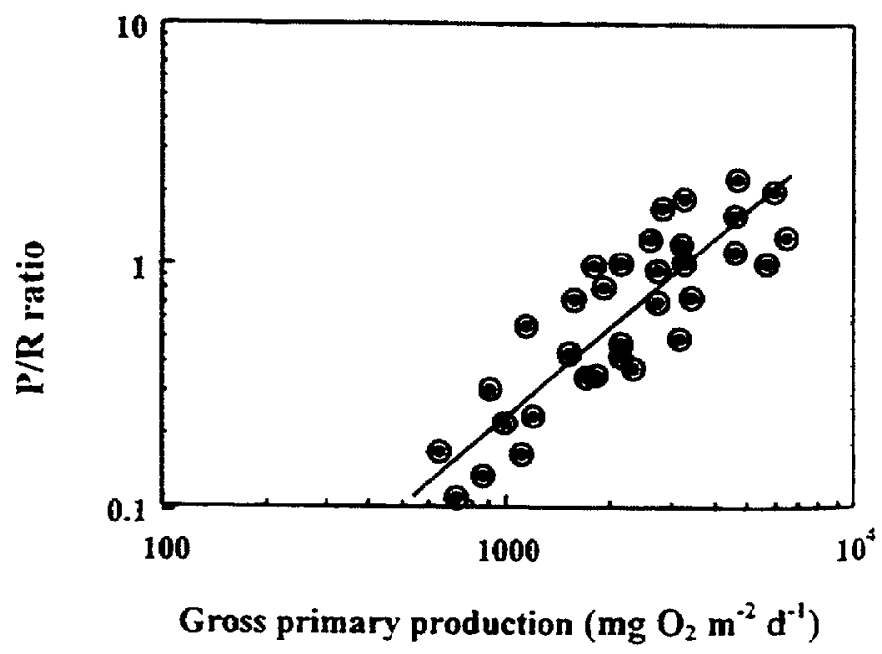

Fig. 2. The relationship between the ratio of depth-integrate: plankion community respiration and production $(P / R)$ and the depth-integrated gross production $(P)$ in the subtropical NE Atlantic The solid line represents the fitted regression cquation. 


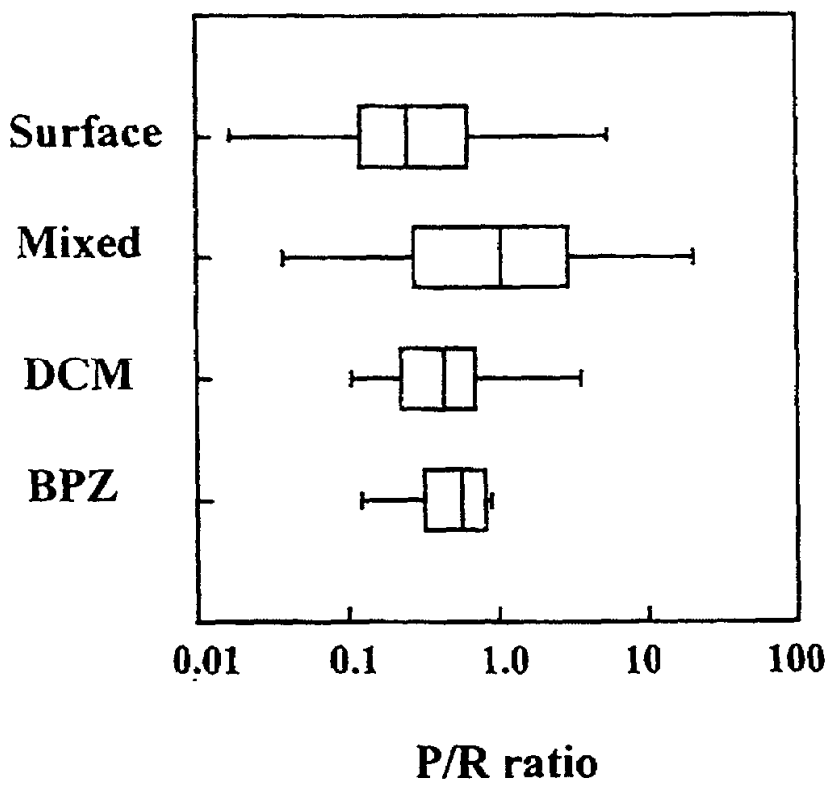

Fig. 3. The distribution of the $P / R$ ratio at different depths in the subtropical NE Allantic. Surface $(\sim 5 \mathrm{~m})$, mixed $(30-50 \mathrm{~m})$. deep chlorophyll a maximum (DCM, $50-110 \mathrm{~m}$ ), and botiom of photic layer (BEZ, the depth receiving $1 \%$ of the surface irradiance [60-130 m]). The boxes enclose the 25 and $75 \%$ percentiles of the data, the central line represents the median, and the bars encompass $95 \%$ of the data.

Metazoan zooplankton, in particular, have been found to respire an equivalent to $7.4 \%$ of the primary production in the area studied (Hernández-León et al. 1999), which should en. hance the heterotrophy of the system. Provided the mean vertically integrated $P / R$ ratio in the data set and an annual primary production of $1.14 \mathrm{Pg} \mathrm{C}$ in the $5.2610^{6} \mathrm{~km}^{2}$ covered by the subtropical NE Atlantic (Northeast Atlantic Subtropical Gyre and Canary Coastal Current provinces in Longhurst et al. [1995]), we calculate (assuming $P Q=$ respiratory quotient $=1$ ) a conservative annual $\mathrm{CO}_{2}$ release of

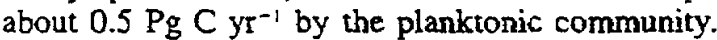

The organic carbon needed to support the net $\mathrm{CO}_{2}$ production of planktonic communities in the subtropical NE Atlantic must be supplied by lateral inputs from the productive, upwelling areas in the NW African coast and atmospherie deposition. Robust evidence for the presence of significant lateral inputs of organic carbon to the subtropical NE Atlantic has been derived from the analysis of sediment trap arrays (Fisher et al. 1996). Upwelling filaments, stretching offshore from the productive NW African coast to the open ocean. have been shown to be effective mechanisms to transfer organic carbon laterally to the subtropical NE Atlantic (Aristegui and others 1997; Barton et al. 1998: Pacheco and Hernández-Guerra 1999). In addition, the subtropical NE Atlantic is known to be the province of the ocean with the highest atmospheric deposition (Barton et al. 1998), although the organic carbon delivered in this form remains to be quantified. This analysis provides evidence for a dominance of heterourophy in the subtropical NE Atlantic and confirms the conclusion that the biota of oligotrophic oceanic systems af- fected by allochthonous inputs of organic matter act as $\mathrm{CO}$, sources.

Carlos M. Duarte and Susana Agusti

Instituto Mediterráneo de Estudios Avanzados (IMEDEA) CSIC-Universitat de les Illes Balears

Calle Miquel Marqués, 21

07190 Esporlas

(Baleares), Spain

Javier Aristegui

Universidad de Las Paimas de Gran Canaria

Departamento de Biologia, Facultad de Ciencias Del Mas Apartado Postal 550

Las Palmas de Gran Canaria, Spain

Natalia González and Ricardo Anadón

Deptartamento Biologia de Organismos y Sistemas

Laboratorio de Ecología

Universidad de Oviedo

33071 Oviedo, Spain

\section{References}

agusti, S., C. M. Duarte, D. Vaqué, M. Hen, J. M. Gasol, and $M$. VIDAL In press. Food web structure and elemental (C. $N$ and P) fluxes in the Eastern tropical North Atlantic. Deep-Sea Res.

Aristegul, J., S. Hernández León, M. F. Montero. A.ND M. Gómez. In press. The seasonal planktonic cycle in coastal wi. ters of the Canary Islands. Scientia Marina.

- AND OTHERS. 1997. The influence of island generated eddies on chlorophyll distribution: A study of mesoscale variation around Gran Canaria. Deep Sea Res. 44: 71-96.

BARTON, E. D.. AND OTHERS. 1998. The transition zone of the Canary Current upwelling region. Prog. Oceanogr. 41: 455-504.

Bender, M.. J. OrChardo. M.-L. Dickson, R. Barber, and $S$. LiNDELY. 1999. In vitro O, fiuxes compared with 'C production and other rate terms during the JGOFS Equatorial Pacific. Deep-Sea Res. II 46: 637-654.

BRYAN, J. R., J. P. Riley. AND P. J. LeB. Williams. 1976. A procedure for making precise measurements of oxygen concentra. tion for productivity and related studies. J. Exp. Mar. Biol. Ecol. 21: 191-197.

Carrit, D. E., and J. H. Carpenter. 1966. Comparison and evaluation of currently deployed modinications of the Winkler method for determining dissolved oxygen in seawater: A NASCO Report. J. Mar. Res. 24: 287-318.

Davenport, R. S. Nelier, A. Hernández-Glifrra, M. J. Rued.A. O. LliNÁs, G. Fisher. AND G. WeFer. 1999. Seasonal and interannual pigment concentration in the Canary Islands region from CZCS data and comparison with observations from the ESTOC. Int. J. Remote Sens. 20: 1419-1433.

\section{Acknowledgments}

We thank A. Hernández-Guerra. E. Marañón, and two anonymous reviewers for useful advice: G. Carteras. P. Satta. L. Viesca, and B. Casas for assistance with the analyses: P. Schlittenhardt and T. Plat1 for inviting J. A. to join the Hudson cruisc: and the commanders and crews of the research vessels for assistance.

The research reponted herein was derived from cruises on board RV Hespérides, Garcia del Cid. and Hudson. within the projects LATITUD I and II (AMB94-0739. MAR98-1676-E) and PB880436 , funded by the Spanish Commission of Science and Technology, and cruises Azores I and II of the CANIGO project (MAS3. CT96-0060), funded by the MAST III program (CE). 
DE LEÓN. A. R.. AND J. G. BraUN. 1973. Ciclo anual de la produccion primaria y su relación con los nutrientes en aguas Canarias. Bol. Inst. Esp. Ocean. 167: $1-24$.

del Giorgio, P. A., J. J. Cole, and A. Cimbleris. 1997. Respiration rates in bacteria exceed plankion production in unproductive aquatic systems. Nature 385: 148-151.

DuARTE, C. M., AND S. Agusti. 1998. The $\mathrm{CO}$, balance of unproductive aquatic ecosysiems. Science 281: 234-236.

- P. A. DEL GIORCIO. AND J. J. COLE. 1999. Is the open ocean beterotrophic? Science 284: 1735b.

Fisher, G., S. Nelier. AND G. Wefer. 1996. Shon-lerm sedimentation puises recorded with a fluorescence sensor and sediment traps at $900-\mathrm{m}$ depth in the Canary basin. Limnol. Oceanogr. 41: $1354-1359$.

Grasshoff. K.. M. Ehrhardt. and K. KREMLING. 1983. Methods of seawater analysis. Verlag Chemie.

HERNÁNDEZ-LEÓN, S., AND OTHERS. 1999. Large-scale and mesoscale distribution of plankton biomass and metabolic activity in the northeastern Central Atlantic. J. Oceanogr. 55: 471-482.

LONGHURST, A., S. SATHyendramath, T. PlatT, aNd C. CAVERHILl. 1995. An estimate of giobal primary production in the ocean from satellite radiometer data. J. Plankion Res. 17: 1245-1271.

Marañón, E. P. holligan, M. Varela, B. Molriño. and A. J. BALE. 2000. Basin-scale variability of phytopiantkon biomass, production and growth in the Allantic Ocean. Deep-Sea Research 1 47: 825-857.
Oudot, C., R. Gerard, P. MORIN, and I. GNingle. 1988. Precise shipboard determination of dissolved oxigen (Winkler procedure) for productivity studies with a commercial sysiem. Limnol. Oceanogr. 33: 146-150.

PaCheCo, M. M., AND A. Herníndeg-Glerra. 1999. Seasonal variability of recurrent phytoplankion pigment patterns in the Canary Island area. Int. J. Remole Sens. 20: 1405-1418.

SherR, E. B., AND B. F. SherR. 1996. Temporal offset in oceanic production and respiration processes implied by seasona: changes in atmospheric oxygen: The role of heterotrophic microbes. Aquat. Microb. Ecol. 11: 91-100.

STRICKLAND, J. D. H. 1960. Measuring the production of marine phyroplankton. Bull. Fish. Res. Board Can. 122: 1-172.

WILLIA.MS, P. J. LEB. 1998. The balance of plankton respiration anc photosynthesis in the open ocean. Nature 394: 55-57. , AND D. G. BOWER. 1999. Determination of organic carbor balance in the oceans from field observations-a re-evaluation Science 284: 1735a.

-, AND N. W. JENKINSON: 1982. A transportable microproces. sor-controlled precise Winkler titration suitable for field statior and shipboard use. Limnol. Oceanogr. 27: 576-584.

Received: 29 May $200 \mathrm{C}$ Amended: 20 November $200 \mathrm{C}$ Accepted: 20 November 200

\section{The heterotrophic bacterial response during a mesoscale iron enrichment experiment (IronEx II) in the eastern equatorial Pacific Ocean}

\begin{abstract}
The response of the heterotrophic bacterial community to iron addition was determined during the mesoscale iron-enrichment experiment conducted in the eastem equatorial Pacific during May-June 1995 (lronEx Il). Bacterial abundance and 'H-leucine incorporation rates were measured for samples collected from the middle of the mixed layer $(15 \mathrm{~m})$ over the course of the iron-induced phytoplankton bloom and its dectine. Bacterial abundance and productivity increased 1.7- and threefold, respeciively, compared to un-enriched waters. Specific growth rates of heterotrophic bacteria increased three- to fourfold. These results demonstrate that iron addition io this high-nitrate, low-chlorophyll region affects both autotrophic and heterotrophic microorganisms and that bacterial carbon demand can be potentially met by the fivefold increase in photosynthetic productivity in the mixed layer.
\end{abstract}

Over the last decade. considerable effort has been directed toward understanding the relationship between phytoplankton productivity and the availability of iron. particularly as the reason for the lack of significant autotrophic growth in high-nitrate. low-chlorophyll (HNLC) regions of the open ocean. The results of iron enrichment incubation experiments conducted in the subarctic North Pacific (e.g.. Marlin and Fitzwatter 1988). equatorial Pacific Ocean (e.g., Martin et al. in the south of Australia (Boyd et al. 2000), strongly suppor the ides that phytoplankton growth in HNLC areas are lim ited, at least in part, by the availability of Fe. These studie have focused primarily on the phytoplankton response to a alleviation of Fe deficiency, presumably because of the cru cial role of $\mathrm{Fe}$ in photosynthesis, chlorophyll synthesis, an nitrate assimilation. Heterotrophic bacteria have been les studied despite their numerical dominance in oligotrophi waters (e.g., Fukuda et al. 1998) and their importance in th cycling of carbon and nutrients, including iron (Tortell et a. 1996). The few studies examining iron limitation of heterc trophic bacterial communities have reached contradictor conclusions, and the relative importance of iron versus dis solved organic matter in controlling the rates of bacteriz growth in HNLC regions is still unclear.

Previous incubation experiments in Fe-depleted region have suggested that Fe enrichment may affect heterotrophi bacteria, either directly by the alleviation of Fe limitation $\mathrm{C}$ indirectly through the effects of enhanced phytoplankto growth and the increased supply of dissolved organic matte suitable for bacterial utilization. During experiments cor ducted in the coastal Southern Ocean (Gerlache Strait). Pal ulski et al. (1996) found that Fe enrichment increased bot heterotrophic bacteria abundance and cell-specific growt 